\title{
Mineral Content of Selected Seaweed Varieties in Southern and North Western Sea of Sri Lanka
}

\author{
M.M. Jayakody, M.P.G. Vanniarachchy* and W.L.I. Wijesekara \\ Department of Food Science and Technology, University of Sri Jayewardenepura, \\ Nugegoda, Sri Lanka
}

Date Received: 15-02-2021

Date Accepted: 02-04-2021

\begin{abstract}
Seaweeds are a rich source of health beneficial bioactive nutraceuticals and currently, they are under-utilised in Sri Lanka. Thus, this study is to get an idea about the possibility of utilising seaweed in Sri Lankan food industry. In the present study, elemental composition analysis of Ulva fasciata obtained

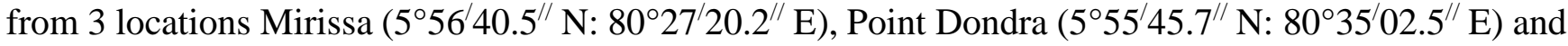
Galle $\left(6^{\circ} 02^{\prime} 01.1^{/ /} \mathrm{N}: 80^{\circ} 12^{\prime} 52.2^{/ /} \mathrm{E}\right)$ and red algae varieties Gracilaria edulis and Gracilaria sp. obtained from Kalpitiya $\left(8^{\circ} 15^{\prime} 40.8^{\prime \prime} \mathrm{N}: 7^{\circ} 46^{\prime} 33.9^{\prime \prime} \mathrm{E}\right.$ and $\left.8^{\circ} 13^{\prime} 35.0^{\prime \prime} \mathrm{N}: 79^{\circ} 43^{\prime} 34.8^{\prime \prime} \mathrm{E}\right)$ respectively. The elemental analysis was carried using X-ray fluorescence (XRF) analyzer. The results revealed that the predominant mineral of $U$. fasciata obtained from the 3 locations and Gracilaria sp. as calcium. While the predominant mineral in G. edulis was potassium. All the 5 varieties have various concentrations of elements such as $\mathrm{K}, \mathrm{Ca}, \mathrm{Mn}, \mathrm{Fe}, \mathrm{Cu}$ and $\mathrm{Zn}$. Significantly high lead content was observed in U. fasciata obtained from Point Dondra. The elemental compositions showed variations among the same species obtained from different locations. The results also revealed that seaweed is a good source of certain essential and trace minerals.
\end{abstract}

Keywords: Ulva fasciata, Gracilaria edulis, Gracilaria sp., minerals, seaweeds

\section{Introduction}

Based on current trends, it has been estimated that more than two planet Earth will be needed by 2050 to support the growing global population (Tiwari and Troy, 2015). With these increments in population there comes a question of sustainably reducing the hunger and fulfilling almost all the basic needs of the population. Thus, utilisation of ocean farms for cultivation of seaweeds and popularisation of seaweed consumption among people would be an option for sustainable food production since the cultivation of seaweeds requires no fresh water, chemical fertilizer, or land, which are some of the significant negative factors of land-based cultivation (Tiwari and Troy, 2015). At the same time, present day consumers are seeking many health promoting food ingredients in their diets. In addition to food supplements, consumption of exotic foods with identified nutritional values such as functional food has also been gaining prominence in several developed countries. The beneficial actions of such food are due to presence of their functional components such as minerals, antioxidants and n-3 fatty acids. Thus there is a need of doing research on compositional analysis of food ingredients that has a potential to be included in human diets (Kumar et al., 2011).

The nutritional composition of seaweeds comprised of protein, lipids, vitamins and minerals (Marsham et al., 2007) It also contains polysaccharides such as alginates, fucans and laminarans, and amino acids of considerable nutritional importance. Algal lipids consist of a high proportion of essential fatty acids such as n-3 polyunsaturated fatty acids (PUFAs).

*Correspondence: mihiripg@sjp.ac.lk

Tel: +94767288380

(C) University of Sri Jayewardenepura 
The research studies have revealed that the mineral content of seaweeds is usually high enough $(8-40 \%)$ to fulfill the recommended daily intakes of essential macro elements and trace elements for human nutrition (Ruperéz, 2002). Generally, seaweeds are a rich source of minerals. This seaweed mineral content is higher than that of terrestrial plants and it varies with seaweed phyllum, geographical origin, seasonal, environmental and physiological factors (Ruperéz, 2002). Larrea-Marín et al., 2010 in their research has also stated that the environmental characteristics of the water in which algae grow such as salinity, turbidity, nutrient content, and heavy metal contamination mostly determine the mineral content they can absorb. Even under similar environmental conditions, mineral composition and content differ greatly between different families, genera and species of macro-algae. Research in this field is of great scientific importance as elements such as $\mathrm{As}, \mathrm{Cd}, \mathrm{Pb}$, and $\mathrm{Sb}$ may be present in seaweeds as a result of environmental contamination while others, including $\mathrm{Ca}, \mathrm{K}, \mathrm{P}, \mathrm{Se}, \mathrm{Mn}, \mathrm{Zn}, \mathrm{Cu}$ etc., which are essential to human beings (Larrea-Marín et al., 2010).

Generally, minerals can be introduced as naturally occurring inorganic substances with a definite chemical composition and an ordered atomic arrangement (Hanif et al., 2006). These minerals are not synthesised in the body, but these are essential ingredients of diet required for normal metabolic activities of body tissues, thus it is essential to get minerals from food. Minerals can be divided in to 3 groups as major elements, trace elements and ultra- trace elements. Major elements include $\mathrm{Na}, \mathrm{K}, \mathrm{Ca}, \mathrm{Mg}, \mathrm{Cl}, \mathrm{P}$, $\mathrm{S}$ which are necessary more than $50 \mathrm{mg}$ /day. Trace elements include, $\mathrm{Fe}, \mathrm{I}, \mathrm{Zn}, \mathrm{Se}, \mathrm{Cu}, \mathrm{Mn}, \mathrm{Cr}, \mathrm{Mo}, \mathrm{Co}$, $\mathrm{Ni}$ which are needed less than $50 \mathrm{mg} /$ day and ultra- trace elements include, $\mathrm{Al}, \mathrm{As}, \mathrm{Ba}, \mathrm{Bi}, \mathrm{Br}, \mathrm{Cd}, \mathrm{Cs}$, $\mathrm{Ge}, \mathrm{Hg}, \mathrm{Li}, \mathrm{Pb}, \mathrm{Sb}, \mathrm{Si}, \mathrm{Sm}, \mathrm{Sn}, \mathrm{Sr}, \mathrm{Tl}, \mathrm{Ti}, \mathrm{Rb}$ which are not essential (Ismail et al., 2011). Each of these minerals has specific functions related to proper growth, development, and physiology of the organism body. Other than major minerals trace elements also have several important roles in human bodies, for instance, some trace elements are essential for enzyme reactions where they attract and facilitate conversion of substrate molecules to specific end products. Some minerals donate or accept electrons in redox reactions that are of primary importance in the generation and utilisation of metabolic energy etc. (Al-fartusie and Mohssan, 2017).

In the Far East and Pacific, there has been a long tradition of utilising seaweeds as sea vegetables, but in Western countries seaweeds were commonly used as sources of phycocolloids, thickening agents and gelling agents for various industrial applications, including uses in foods. France can be named as the first European country to establish a specific regulation concerning the use of seaweeds for human consumption (Mabeau and Fleurence, 1993). Generally, seaweeds play a major role in Asian diets, especially in Japan, China and Korea. Among these three countries, Japan is the most important seaweed consumer since they have a considerable market for seaweeds (Ismail et al., 2011). But in Sri Lanka seaweed is an abundant underutilised natural resource. It has also revealed that the consumption of seaweeds as part of diet has been shown to be one of the most prominent reasons for low incidence of breast and prostate cancer in Japan and China compared to North America and Europe (Kumar et al., 2011). Thus, under this research an elemental analysis was done to determine the suitability to popularise seaweed consumption in Sri Lanka.

\section{Materials and Methods}

\subsection{Sample collection}

U. fasciata samples were collected during June, 2018 from Mirissa $\left(5^{\circ} 56^{\prime} 40.5^{\prime /} \mathrm{N}: 80^{\circ} 27^{\prime} 20.2^{\prime /} \mathrm{E}\right)$, and Point Dondra $\left(5^{\circ} 55^{\prime} 45.7^{\prime \prime} \mathrm{N}: 80^{\circ} 35^{\prime} 02.5^{\prime /} \mathrm{E}\right)$ of Matara and Galle $\left(6^{\circ} 02^{\prime} 01.1^{\prime \prime} \mathrm{N}: 80^{\circ} 12^{\prime} 52.2^{\prime /} \mathrm{E}\right)$. Gracilariya edulis and Gracilaria sp. were collected during September, 2018 from Kalpitiya $\left(8^{\circ} 15^{\prime} 40.8^{\prime \prime}\right.$ $\mathrm{N}: 79^{\circ} 46^{\prime} 33.9^{\prime /} \mathrm{E}$ and $8^{\circ} 13^{\prime} 35.0^{\prime /} \mathrm{N}: 79^{\circ} 43^{\prime} 34.8^{/ /} \mathrm{E}$ ) respectively. All the algal samples were harvested manually from the respective locations and then transported to the laboratory in polythene bags. They were thoroughly washed and cleaned to remove epiphytes and detritus attached to the fronds. 
Algal samples were dried at $60^{\circ} \mathrm{C}$, in a drying cabinet for 8 hours. Then they were pulverised using an agate mortar into small particles (Drying and pulverizing was done without contacting metal surfaces), sieved through 63 micron sieve. Then they were stored in room temperature, sealed in polypropylene bags till further used in analysis.

\subsection{Determination of mineral content}

$0.2 \mathrm{~g}$ of the sieved sample was compressed in a pellet press and a compressed pellet was prepared. Each compressed pellet was subjected to X-ray fluorescence emitted by XRF instrument (DX-MO8×045s) in order to determine the levels of metals. Cadmium could not be detected due to the nature of the molybdenum cathode used in the instrument.

\subsection{Statistical analysis}

All analysis was performed in duplicates. All data are presented as mean values \pm SD and the mean values were analysed by one-way ANOVA and Tukey comparison at $\mathrm{p}<0.05$ by MINITAB 17 to detect significant differences among groups.

\section{Results}

Mineral composition in dry basis of $U$. fasciata obtained from the above mentioned three locations are tabulated in Table 1.

Table 1: Elemental analysis of $U$. fasciata of the 3 locations in ppm by XRF.

\begin{tabular}{lccc}
\hline Element & Mirissa $(\mathrm{ppm})$ & Point Dondra $(\mathrm{ppm})$ & Galle $(\mathrm{ppm})$ \\
\hline $\mathrm{K}$ & $3455.00 \pm 233.00^{\mathrm{a}}$ & $1865 \pm 21.2^{\mathrm{b}}$ & $6085 \pm 262^{\mathrm{c}}$ \\
$\mathrm{Ca}$ & $18300.00 \pm 2121.00^{\mathrm{a}}$ & $13200 \pm 707 \mathrm{a}^{\mathrm{b}}$ & $9510 \pm 28.3^{\mathrm{b}}$ \\
$\mathrm{Ti}$ & $\mathrm{ND}$ & $965.0 \pm 77.8^{\mathrm{a}}$ & $482.5 \pm 68.6^{\mathrm{b}}$ \\
$\mathrm{Cr}$ & $\mathrm{ND}$ & $102.50 \pm 13.44$ & $\mathrm{ND}$ \\
$\mathrm{Mn}$ & $73.05 \pm 3.46^{\mathrm{a}}$ & $97.80 \pm 13.01^{\mathrm{a}}$ & $97.35 \pm 1.06^{\mathrm{a}}$ \\
$\mathrm{Fe}$ & $657.50 \pm 71.40^{\mathrm{b}}$ & $1850 \pm 156^{\mathrm{a}}$ & $637 \pm 14.1^{\mathrm{b}}$ \\
$\mathrm{Ni}$ & $\mathrm{ND}$ & $15.90 \pm 0.71$ & $\mathrm{ND}$ \\
$\mathrm{Cu}$ & $6.89 \pm 1.61^{\mathrm{b}}$ & $7185 \pm 445^{\mathrm{a}}$ & $188.5 \pm 30.4^{\mathrm{b}}$ \\
$\mathrm{Zn}$ & $12.25 \pm 0.21^{\mathrm{b}}$ & $1145.0 \pm 77.8^{\mathrm{a}}$ & $56.35 \pm 5.20^{\mathrm{b}}$ \\
$\mathrm{Pb}$ & $\mathrm{ND}$ & $2970.0 \pm 113.1^{\mathrm{a}}$ & $128.0 \pm 18.4^{\mathrm{b}}$ \\
$\mathrm{Bi}$ & $\mathrm{ND}$ & $42.90 \pm 4.81$ & $\mathrm{ND}$ \\
$\mathrm{Br}$ & $428.50 \pm 30.40^{\mathrm{a}}$ & $219.50 \pm 9.19^{\mathrm{b}}$ & $185.00 \pm 4.24^{\mathrm{b}}$ \\
$\mathrm{Sr}$ & $214.00 \pm 17.00^{\mathrm{a}}$ & $76.60 \pm 2.55^{\mathrm{b}}$ & $83.25 \pm 1.91^{\mathrm{b}}$ \\
$\mathrm{As}$ & $7.08 \pm 0.82$ & $\mathrm{ND}$ & $\mathrm{ND}$ \\
\hline
\end{tabular}

Values for the elemental analysis are mean $\pm S D ; n=2$. Means in the same row followed by different letters are significantly different $(\mathrm{p}<0.05)$.

Results depicted in the table have revealed that $U$. fasciata contain major minerals such as $\mathrm{K}$ and $\mathrm{Ca}$, Trace minerals such as, $\mathrm{Fe}, \mathrm{Zn}, \mathrm{Cu}, \mathrm{Mn}, \mathrm{Cr}$, Ni. The results in Table 1 represent the variations in elemental compositions of wild type $U$. fasciata in different locations of the same season in the year. Results depict drastic variations in mineral compositions obtained from the three locations. Among all the minerals Calcium is the dominant mineral in $U$. fasciata obtained from all the three locations. $\mathrm{K}$ is also present in a considerable higher level. In the sample obtained from Mirissa, Down south, Matara, Sri Lanka, the decreasing order of major, trace and ultra-trace minerals are $\mathrm{Ca}>\mathrm{K}>\mathrm{Fe}>\mathrm{Br}>$ $\mathrm{Sr}>\mathrm{Mn}>\mathrm{Zn}>\mathrm{As}>\mathrm{Cu}$. The decreasing order in composition of all major, trace and ultra-trace minerals in the sample obtained from Point Dondra, Down South, Matara, Sri Lanka are $\mathrm{Ca}>\mathrm{Cu}>\mathrm{Pb}>\mathrm{K}>\mathrm{Fe}>$ 
$\mathrm{Zn}>\mathrm{Br}>\mathrm{Cr}>\mathrm{Mn}>\mathrm{Sr}>\mathrm{Bi}>\mathrm{Ni}$. And the decreasing order of all major, trace and ultra-trace minerals in the sample obtained from Galle, Down South, Sri Lanka are $\mathrm{Ca}>\mathrm{K}>\mathrm{Fe}>\mathrm{Ti}>\mathrm{Cu}>\mathrm{Br}>\mathrm{Pb}>\mathrm{Mn}>\mathrm{Sr}>\mathrm{Zn}>\mathrm{Ni}$. Fe is the abundant and highest present trace element in the samples obtained from Mirissa and Galle. $\mathrm{Cu}$ is the abundant and highest present mineral in the sample obtained from point Dondra. Lead has been reported in $U$. fasciata samples obtained from point Dondra and Galle but not in samples obtained from Mirissa. Arsenic has been reported in U. fasciata samples obtained from Mirissa but not in other two locations.

Mineral composition in dry basis of G. edulis and Gracilaria sp. obtained from above mentioned locations are tabulated in Table 2.

Table 2: Elemental analysis of G. edulis and Gracilaria sp. by XRF.

\begin{tabular}{lcc}
\hline Element & G. edulis $(\mathrm{ppm})$ & Gracilaria $\mathrm{sp} .(\mathrm{ppm})$ \\
\hline $\mathrm{K}$ & $23750.00 \pm 1344.00$ & $8720.00 \pm 368.00$ \\
$\mathrm{Ca}$ & $8660.00 \pm 552.00$ & $34200.00 \pm 990.00$ \\
$\mathrm{Ti}$ & $\mathrm{ND}$ & $2095.00 \pm 49.50$ \\
$\mathrm{Mn}$ & $653.00 \pm 238.00$ & $238.00 \pm 22.60$ \\
$\mathrm{Fe}$ & $2245.00 \pm 35.40$ & $7385.00 \pm 304.00$ \\
$\mathrm{Cu}$ & $222.00 \pm 7.07$ & $393.50 \pm 7.78$ \\
$\mathrm{Zn}$ & $54.50 \pm 3.25$ & $93.55 \pm 0.49$ \\
$\mathrm{~Pb}$ & $174.50 \pm 2.12$ & $204.00 \pm 8.49$ \\
$\mathrm{Br}$ & $436.00 \pm 7.07$ & $947.50 \pm 38.90$ \\
$\mathrm{Rb}$ & $\mathrm{ND}$ & $15.15 \pm 0.77$ \\
$\mathrm{Sr}$ & $59.50 \pm 0.56$ & $567.00 \pm 19.80$ \\
\hline
\end{tabular}

According to the results in Table 2, the decreasing order of elemental composition of G. edulis is $\mathrm{K}>\mathrm{Ca}>\mathrm{Fe}>\mathrm{Mn}>\mathrm{Br}>\mathrm{Cu}>\mathrm{Pb}>\mathrm{Sr}>\mathrm{Zn}>\mathrm{Rb}$. And the decreasing order of elemental composition of Gracilaria sp. is $\mathrm{Ca}>\mathrm{K}>\mathrm{Fe}>\mathrm{Ti}>\mathrm{Br}>\mathrm{Sr}>\mathrm{Cu}>\mathrm{Mn}>\mathrm{Pb}>\mathrm{Zn}$. The predominant mineral in G. edulis is $\mathrm{K}$ while the predominant mineral in Gracilaria sp. is Ca. A wide variation in mineral compositions can be seen in G. edulis and Gracilaria sp. Fe was the most abundant trace element and is the highest in both species. $\mathrm{Zn}$ is the trace element which is present in lowest level. Lead has been reported in both Gracilaria sp. and G. edulis.

\section{Discussion}

Measurable differences were observed in mineral compositions of samples analysed in the study. Tiwari and Troy (2015) have stated that different mineral contents in seaweeds vary, depending on diverse seaweed genera, seasonal differences, geographic location, light intensity, and seaweed type such as wild type and cultivated type. Ulva samples used in the study are from the same genus and species. But they have been plucked from different geographical locations with different water quality parameters. Hence, there can be variations in mineral compositions of these samples.

Consumption of mineral rich food in human diet is essential for the proper functioning of the human body. The Recommended daily Dietary Allowance (RDA) values for $\mathrm{Ca}, \mathrm{K}, \mathrm{Fe}, \mathrm{Zn}, \mathrm{Cu}, \mathrm{Mn}, \mathrm{Cr}$ and Ni are 800-1,200 mg, 550-5,625 mg, 10-18 mg, $15 \mathrm{mg}, 1-3 \mathrm{mg}, 1-5 \mathrm{mg}, 0.02-0.2 \mathrm{mg}$ and 0.13-0.4 $\mathrm{mg}$ respectively (Obiajunwa et al., 2002). Diseased states due to lack of adequate minerals is well documented. Thus, mineral rich foods should be consumed to achieve these RDA values. Especially inadequate levels of mineral intake will hinder the proper metabolism and growth of the body. For instance, the index disease for $\mathrm{Ca}$ is Osteoporosis. Results of the analysed samples in tables 1 and 2 show that all the analysed samples are very rich in $\mathrm{Ca}$. All the analyzed five samples are also rich in $\mathrm{Zn}$. $\mathrm{Zn}$ is 
essential in the normal functioning of over 100 enzyme systems in the body. Campbell (2001) and Ismail et al. (2011) have stated that $\mathrm{Zn}$ is a coenzyme for over 200 enzymes which are involved in immunity, new cell growth, acid base regulation etc. A deficiency in one mineral may result in a deficiency of another. Zn deficiency may cause $\mathrm{Cu}$ deficiency. A patient with $\mathrm{K}$ deficiency will also be depleted in $\mathrm{Mg}$ (Deraniyagala et al., 1994). Another important fact is that too much consumption of minerals will be toxic to human body. Thus, meeting the adequate Recommended Dietary Allowance of minerals daily is of great importance for proper functioning of human body. According to the results, all the analyzed seaweed samples are very rich in Potassium and Calcium. Potassium is an essential mineral for the proper functioning of the human body. The major functions of Potassium are the maintenance of the resting membrane potential of the cells and the maintenance of the intracellular osmolarity. Thus consumption of potassium rich diets is essential for proper functioning of the body as well as to maintain the proper $\mathrm{Na} / \mathrm{K}$ ratio (Ekmekcioglu et al., 2016).

According to the results in Table 1, presence of lead has been detected in the samples obtained from Point Dondra and Galle. The results revealed that seaweed sample obtained from Point Dondra contains an amount of 2,970.0 $\pm 113.1 \mathrm{ppm}$ lead while the sample obtained from Galle contains an amount of $128.0 \pm 18.4 \mathrm{ppm}$ lead. But lead was not detected in the sample obtained from Mirissa. According to the first evaluation of lead by the Joint FAO/WHO Expert Committee on Food Additives which dates back to 1972, a provisional tolerable weekly intake (PTWI) was set to $3 \mathrm{mg}$ of lead per person, corresponding to $50 \mu \mathrm{g} / \mathrm{kg}$ body weight (b.w.). This value referred to all sources of lead exposure and applied just to the adult population. The PTWI was based on the assumption that an average person absorbs 60 to $70 \mu \mathrm{g}$ of lead per day $(1 \mu \mathrm{g} / \mathrm{kg}$ b.w. per day) and was allocated as follows: $20 \mu \mathrm{g}$ from air, $10 \mu \mathrm{g}$ from water and $40 \mu \mathrm{g}$ from food (European Food Safety Authority, 2010). Thus, the lead contents present in the samples obtained from Point Dondra and Mirissa are too high. Research have revealed that macro algae are often considered as a valuable indicator of heavy metal pollution in coastal areas because of their high accumulation potentials facilitated by the presence of thiols and peptides. Among macro algae, Ulva sp. has a great potential as a bio monitor due to its wide distribution and large size. It also states that macro algae were found to contain a high concentration of $\mathrm{Fe}, \mathrm{Cu}, \mathrm{Zn}, \mathrm{Pb}$ and $\mathrm{Cd}$ when collected along the urban coastlines because of the input of these metals from sewage, metal product manufacturing, leather tanning, electroplating, the use of fertilizers and petroleum refining (Lee and Wang, 2001). So the reason for this reported lead content might be due to the contamination of the sea by the fuel effluents of the boats in harbors located at Point Dondra and Galle. Ti, $\mathrm{Cr}, \mathrm{Pb}$ and $\mathrm{Bi}$ have not recorded in the sample obtained from Mirissa, Down South, Matara, Sri Lanka. Bi and As have not recorded in the sample obtained from Galle, Down South, Sri Lanka. Arsenic is identified as a highly toxic element and its presence in food stuff is a matter of concern to the well-being of both humans and animals. The regulations in France and the United States has stated the maximum permissible limits of 3 $\mathrm{mg} / \mathrm{kg}$ of dry weight (dw) inorganic arsenic, whereas in New Zealand and Australia states a lower limit as $1 \mathrm{mg} / \mathrm{kg} \mathrm{dw}$ (Almela et al., 2002). Drastic elevations in $\mathrm{Cu}$ contents can be seen in U. fasciata samples obtained from Point Dondra and Galle. The reason behind this elevation is unknown and it should be analyzed through further research studies. Kumar et al., 2011 has also studied mineral composition of $U$. fasciata from Saurashtra coast of India and their results are much closer to the results obtained from this study except for $\mathrm{Fe}, \mathrm{Cu}$ and $\mathrm{Zn}$ content of samples from point Dondra, Sri Lanka and $\mathrm{Cu}$ content of samples obtained from Galle, Sri Lanka. Major minerals they have found in their sample were $\mathrm{K}, \mathrm{Na}$, $\mathrm{Ca}$ and $\mathrm{Mg}$. Deviation of certain values may be due to use of samples from areas with different water quality parameters and use of different analysis techniques.

Table 2 shows the mineral composition of G. edulis and Gracilaria sp. respectively. A variation in mineral compositions can be seen in these two varieties also. G. edulis and Gracilaria sp. are 2 species of the same genus. These 2 species are also from 2 locations in Kalpitiya area. Gracilaria sp. samples 
were collected from the sea shore and G. edulis samples were collected from a middle of a lagoon with different water quality parameters. Ruperez (2002) has also stated in their research that mineral content has been shown to vary according to seaweed species, oceanic residence time, geographical place of harvest, wave exposure, seasonal, annual, environmental and physiological factors, type of processing and method of mineralisation, hence there should be a variation in the elemental composition of G. edulis and Gracilaria sp. since these two species are from various geographical locations. Lead has been reported in various quantities in both the species. Previous research "Mineral and Protein Contents of some Marine Algae from the Coastal Areas of Northern Sri Lanka" has revealed the mineral composition of G. edulis harvested from Mandaitivu, Sri Lanka and Nainative, Sri Lanka. According to the results $\mathrm{Na}, \mathrm{K}, \mathrm{Ca}, \mathrm{Mg}$ in $\mathrm{g} / 100 \mathrm{~g}$ and $\mathrm{Cu}, \mathrm{Zn}, \mathrm{Mn}, \mathrm{Ni}, \mathrm{Pb}$ and $\mathrm{Cd}$ in $\mathrm{ppm}$ of G. edulis harvested from Mandativu are $1.61,13.49,3.55,0.68,5.3,9.2,397.3,24.0,8.3$ and 3.3 respectively (Mageswaran and Sivasubramaniam, 1984). These results are different from the results obtained during this study. In that study results for $\mathrm{Na}$ and $\mathrm{K}$ have obtained from Corning Model 400 flame photo- meter. Results for Ca and $\mathrm{Mg}$ have obtained from titrating a known volume of the test solution with standard EDTA. Results for copper, manganous, nickel, zinc, cadmium, cobalt and chromium were determined using Varian Model 1,275 atomic absorption spectrophotometer. The amount of lead present has determined using Corning Model 252 colorimeter after complexing with dithizone. Thus, the deviation of results may be due to use of different analysis techniques.

Generally, metal content of water where seaweed has grown directly affect for the mineral composition of that seaweed variety. Jinadasa et al. (2014) has stated in their research that many marine animals can accumulate heavy metals such as zinc, copper, mercury, cadmium and lead in their body. At the same time, it has stated that, due to pollution in the marine environment, bioaccumulation of metals in marine organisms has increased and the heavy metal accumulation in molluscs positively correlates with the metal concentration in the diet and ambient water. Results of the study shows heavy metals like $\mathrm{Pb}, \mathrm{Cd}, \mathrm{Hg}, \mathrm{Co}$ and $\mathrm{Cr}$ accumulation in analyzed sea cucumber which indicates heavy metal pollution in North Western sea of Sri Lanka (Jinadasa et al., 2014). Thus, these heavy metals can present in Gracilaria sp. which was plucked from sea area of Kalpitiya in North Western sea of Sri Lanka. But G. edulis was harvested from a lagoon in Kalpitiya and not from the sea. This lagoon is highly utilised by fishing boats of villages. These boats use petroleum oil which contains heavy metals like Pd and Cd. These fuel effluents contaminate the lagoon, thus these heavy metals of fuel effluents can present in G. edulis which is harvested from the lagoon.

\section{Conclusion}

U. fasciata, G. edulis and Gracilaria sp. are good sources of essential minerals such as $\mathrm{Ca}$ and $\mathrm{K}$ and trace minerals such as $\mathrm{Fe}, \mathrm{Zn}, \mathrm{Cu}$ and $\mathrm{Mn}$. The mineral composition of $U$. fasciata has shown variation with the change in geographical location. Toxic heavy metals that were present in $U$. fasciata was $\mathrm{Pb}$ and As. Toxic heavy metals that were present in G. edulis and Gracilaria sp. were Pb. Thus seaweeds, to be utilised in the food industry should be cultivated in areas with good water quality parameters in Sri Lanka.

\section{Acknowledgment}

This article is based on the work supported by University Research Grants (Grant No. ASP/ 01/RE/SCI/2019/16), University of Sri Jayewardenepura, Nugegoda, Sri Lanka. The authors would also like to acknowledge the support provided by Director General Mr. T.M.R. Tennekoon of Sri Lanka Atomic Energy Board for providing the XRF facility to carry out elemental analysis.

\section{Funding}

This work was supported by University Research Grants (Grant No. ASP/01/RE/SCI/2019/16), University of Sri Jayewardenepura, Nugegoda, Sri Lanka. 


\section{References}

Al-fartusie, F. and Mohssan, S.N., 2017. Essential Trace Elements and Their Vital Roles in Human Body. Indian Journal of Advances in Chemical Science, 5:127-136.

Almela, C., Algora S., Benito, V., Clemente, M.J., Devesa, V., Suner, M.A., Velez, D. and Montoro, R., 2002. Heavy metal, total arsenic, and inorganic arsenic contents of algae food products. Journal of Agricultural and Food Chemistry, 50:918-923.

Campbell, J.D., 2001. Lifestyle, minerals and health. Medical Hypotheses, 57:521-531.

Deraniyagala, S.A., Mudalige, K.T., Anula, H.M. and Jamburuthugoda, M.Y.P.R., 1994. Some micronutrient and macronutrient contents some Sri Lanka food varieties. Journal of Science, 5:93-102.

Ekmekcioglu, C., Elmadfa, I., Meyer, A.L. and Moeslinger, T., 2016. The role of dietary potassium in hypertension and diabetes. Journal of Physiology and Biochemistry, 72:93-106.

European Food Safety Authority (EFSA) 2010. Scientific Opinion on Lead in Food. EFSA Journal, 8:1570.

Hanif, R., Iqbal, Z., Iqbal, M., Hanif, S. and Rasheed, M., 2006. Use of vegetables as nutritional food: role in human health. Journal of Agricultural and Biological Science, 1:18-22.

Ismail, F., Anjum, M.R., Mamon, A.N. and Kazi, T.G., 2011. Trace metal contents of vegetables and fruits of hyderabad retail market. Pakistan Journal of Nutrition, 10:365-372.

Jinadasa, B.K.K.K., Samanthi, R.I. and Wicramsinghe, I., 2014. Trace Metal Accumulation in Tissue of Sea Cucumber Species; North-Western Sea of Sri Lanka. American Journal of Public Health Research, 2:1-5.

Kumar, M., Kumari, P., Trivedi, N., Shukla, M.K., Gupta, V., Reddy, C.R.K. and Jha, B., 2011. Minerals, PUFAs and antioxidant properties of some tropical seaweeds from Saurashtra coast of India. Journal of Applied Phycology, 23:797-810.

Larrea-Marín, M.T., Pomares-Alfonso, M.S., Gomez-Juaristi, M. and Sanchez-Muniz, F.J., 2010. Validation of an ICP-OES method for macro and trace element determination in Laminaria and Porphyra seaweeds from four different countries. Journal of Food Composition and Analysis, 23:814-820.

Lee, W. and Wang, W., 2001. Metal accumulation in the green macroalga Ulva fasciata : effects of nitrate , ammonium and phosphate. Science of the Total Environment, 278:11-22

Mabeau, S. and Fleurence, J., 1993. Seaweed in food products: biochemical and nutritional aspects. Trends in Food Science and Technology, 4:103-107.

Mageswaran, R. and Sivasubramaniam, S., 1984. Mineral and protein contents of some marine algae from the coastal areas of northern Sri Lanka. Journal of the National Science Foundation of Sri Lanka, 12:179.

Marsham, S., Scott, G.W. and Tobin M.L., 2007. Comparison of nutritive chemistry of a range of temperate seaweeds. Food Chemistry, 100:1331-1336.

Obiajunwa E.I., Adebajo A.C. and Omobuwajo O.R., 2002. Essential and trace element contents of some Nigerian medicinal plants. Journal of Radioanalytical and Nuclear Chemistry, 252:473-476.

Ruperéz P., 2002. Mineral content of edible marine seaweeds. Food Chemistry, 79:23-26.

Santoso J., Gunji S., Yoshie-Stark Y. and Suzuki T., 2006. Mineral Contents of Indonesian Seaweeds and Mineral Solubility Affected by Basic Cooking. Food Science and Technology Research, 12:59-66.

Tiwari B.K. and Troy D.J., 2015. Seaweed Sustainability: Food and Non-Food Applications. In: Seaweed Sustainability, 1-6. 